\title{
Nursing Students' Attitudes Toward Simulation Technology in Nursing Education
}

\author{
https://doi.org/10.3991/ijet.v14i14.10571 \\ Mohammad Salih Awad, Mohanned Khailil Abdullah ${ }^{(凶)}$, Radhwan Hussein Ibrahim \\ University of Mosul, Mosul, Iraq \\ nursing@uomosul.edu.iq \\ Rezgar Khalil Abdullah \\ Ministry of Health, Mosul, Iraq
}

\begin{abstract}
This paper investigates the usefulness of simulation technology in nursing education from the students' point of view. A quantitative method for data collection has been used. Participants were recruited from three nursing grads, covering six semesters. Twenty percent of the whole participants in each course and semester were randomly selected to be the sample of the study. The initial sample consisted of 150 students. Grade one students $(\mathrm{N}=141)$ were excluded as they do not use simulation in their curriculum. The study was conducted in the College of Nursing/the University of Mosul during the period from January 2019 to March 2019. KidSim ATTITUDES questionnaire was conducted as a tool to assess students' attitudes towards using simulation technology in Nursing Education. Data management and analysis were performed by using the SPSS 25 . Statistical significance was analyzed using analysis of variance and t-tests as appropriate. Significance levels were set at the $1 \%$ level using the student t-test. The finding suggests that most of the student show positive attitudes towards using simulation technology in Nursing education (42\%48.9\%) expressed about their (agreed-strongly agreed regarding Relevance of Simulation in nursing. In general, this study has found that Mosul Nursing students has positive attitudes towards using simulation in their teaching and training.
\end{abstract}

Keywords - Attitudes; Nursing, simulation

\section{Introduction}

Education plays an important role in the globalization era. Competition in the education sector is increasing. Thus, each college/university needs to have added values to compete with other colleges/universities and win the competition. In order to achieve this goal, they have to increase the capabilities to meet the demands of the society for formal education. Higher education is a strategic sector that can generate high quality human resources. [1] Integration of information technology is of an important essence for modern educational systems as it acts as an effective tool for delivery of education to its users. Education and research complements technology, 
which in return provide innovations in learning methods. Information technology has accelerated processes: broaden scope and apt access to education. The usage of information technology (IT), systems and applications have gone through tremendous growth in the last decade [2-3]. Twenty-one century is characterized with remarkable expansions in information technology. The past twenty years have seen increasingly rapid advances in the field of Nursing education. Teachers and nurses face great difficulties and challenges in bridging the gap between laboratory teaching, simulations, and the transfer of information and skills to be applied in the practice for providing direct nursing care to patients. It is clear that the simulation system provides good educational opportunities, but from the point of view of many, the place of direct clinical trials should not be replaced. [4-9]. Simulation is a rising subject recently, along with the methods and application techniques of simulation researching deeply, with digital computer the simulation to practice system or imaginary system has been more and more recognized. Due to high and new techniques that have progressed such as net technique, graphics and image technique, multimedia, software engineering, information processing and auto-control etc., these have expedited the progressing step of simulation technique [8]. There are many questions that are constantly raised about the simulation positive impact on the outputs of education, and if there is any evidence research that confirms the expected benefits of simulators in training of nursing students [6-9]. Simulation is an actually influential instruction method that motivated students and obliges them to thinking logically and use of critical thinking approach, and offers a prospect for insightful education and mixing of the student's knowledge and practice [10-14]. World Health Organization categorized simulations levels into three types that frequently used: High fidelity which is closer to the real setting, moderate fidelity, and low fidelity simulation [15]. Simulation is not a technology, it is an approach, that is used to construct a planned capability to aid in attaining essential skills and safeguard patients and well-being [16-18]. Recently, increased interest in simulation as a means of training and development of skills and ways of thinking among nursing students and this concern came with the idea of developing curricula and adapting to the strategies of learning and to meet the need of scholars [19-20]. Furthermore, simulation was found to have significant impact on different instructive output like self-confidence, information gaining, and clinical skills [21]. Although the literature stated simulation had a good effect on many education outputs, several nursing students perceived simulation as not matching the real practice setting, and uneasy technique to learn [22]. Like these negative opinions may inhibit the process of education \& effect student's engagement and the fidelity of simulation. [2325]. In order to develop effective nursing education programs, the perceptions, attitudes, and feelings of nursing students towards the use of simulation in their education should be studied.

\section{Aims of the Study}

This paper aims to investigates the effectiveness of simulation technology on nursing education from the point of view of student themselves. 


\section{Review of Literatures}

Simulation has been used widely in the clinical training of health-care students and professionals. It is a valuable strategy for teaching, learning and evaluating clinical skills at different levels of nursing and midwifery education: undergraduate, postgraduate and lifelong education [26-27]. Simulation has a positive impact on students, educators, and the individuals, groups and communities they care for, as well as on education and health organizations. The principal aims of simulation as a teaching method are to improve quality of care and ensure patient safety. The simulation techniques were evaluated through the perceptions of nursing students in the Prince et.al. study [28], which used typical scenarios about Medical-surgical cases. A pre-posttest questionnaire was completed by 52 students. The results of the study indicated positive attitudes towards the use of simulation technology in nursing education and indicated that it helped them to use critical thinking in solving problems. Leonard and others [29] assessed the perceptions of 48 nursing students about using simulation in their studies. Students' answers to the study tool indicated that the simulation provided an appropriate learning environment for teaching nursing practices. Another study was conducted by Wotton et al. [30] on nursing students in their third year of study aimed at evaluating their perceptions and attitudes about simulation technology in teaching nursing practices. Analysis of the students' responses indicated that the simulation is fun and the ability to face challenges and deal with confusion as a natural component in the training phase. Nursing students' perceptions of simulations were also evaluated and compared according to the stages of the study. Eighty-six students were randomly assigned to groups, and they solved a patient problem using a highfidelity simulator, a static costume, or a paper-pencil suit. Data analysis indicated the satisfaction of nursing students with the use of scenarios regardless of the simulated methods used [31]. The attitudes and perceptions of Jordanian nursing students toward simulation as an educational strategy, was investigated by Gharaibeh et al. [32] a convenience sample of 413 Jordanian nursing students completed The Arabic translated version of KidSIM ATTITUDES scale. The total attitude score was encouraging with significant differences between first, second- and third-year students. Post hoc analyses showed the lowest attitude mean score occurring in the second-year nursing students.

\section{$4 \quad$ Methods}

\subsection{Ethical considerations}

This study was approved by the council of College of Nursing at the University of Mosul, Iraq. Study participants were not exposed to harm in any ways whatsoever. Anonymity, privacy and dignity of student were prioritized. No any conflicts of interests and no any advantages were given to the student. Formal consent was obtained from the students before the study and the protection of their identities were ensured. 


\subsection{Study design}

By employing quantitative descriptive modes of enquiry, the authors attempt to illuminate the attitudes of the Nursing students towards using simulation in nursing education as a dependent variable. It also investigated the extent to which these trends are influenced by the student's gender, grade, semesters in which the student is enrolled as independent variables.

\subsection{Study sample}

The target population of the study is the College of Nursing students at the University of Mosul for the academic year (2018-2019). The total number is (671) divided into six Courses: (Fundamentals of Nursing (141); Adult Nursing II (218) students, Pediatric Nursing (74) students, Maternal and Child Health Nursing (81) students, Community Health Nursing (75) students, and Mental Health Nursing (82) students). Participants were recruited from three nursing grads, covering six semesters. Twenty percent of the whole students in each Course and semester were randomly selected, the initial sample consisted of 150 students. Grade one students $(\mathrm{N}=141)$ were excluded as they do not use simulation in their curriculum.

\subsection{Setting}

This study was conducted in a College of Nursing in the University of Mosul during January 2019 to March 2019. Currently, the total number of students enrolled in the different programs offered in the College of Nursing is about 712 undergraduate nursing students.

\subsection{Research tool}

KidSim ATTITUDES questionnaire: It was a 30 -item questionnaire prepared by Sigalet et al. [33] as a tool to evaluate student's attitudes toward using of simulation technology in Nursing Education the time required to complete the scale is approximately 15 minutes. a five option Likert-type scale that range from $1=$ strongly disagree, to $5=$ strongly agree; were used to answer on questionnaire statements and the total score ranged between 30 and 150. there is no reverse coding. The questionnaire was translated into Arabic and translated to English again.

The socio-demographic sheet: The student's demographic characteristics measured in this study were self-reported (gender, age in years, grade, previous exposure to simulation. Validity and Reliability of the scale: face validity was determined through submitted a copy of scale to panel of (10) faculty member and experts in the field of the study (Nursing Education, Educational psychology, biostatistics). Reliability was measured through application of test-retest approach on 10 students who's randomly selected and then they were excluded for the original study. 
Statistical analysis: Data management and analysis were performed using SPSS 25 (2018). Statistical significance was analyzed using analysis of variance and t-tests as appropriate. Significance levels were set at the $1 \%$ level using the student t-test.

\section{$5 \quad$ Results}

As can be seen from the table (1), (77.8\%) of nursing students shows their agreement about "Relevance of Simulation". The total mean score for IPE and communication were (3.46) (3.39) respectively, which reveals that the student has neutral opinion. (Table 2) (Table 3). The Chi-square test show significant association in relation to roles and responsibilities of simulation in education, the overall mean scores response to this sub-scale questions was (4.21), that explore $(84.2 \%)$ of students has very strongly agreement, Table (4). When the participants were asked about "Situation Awareness", the majority responses (68\%) shows that positive attitudes. Interestingly, the female students show more positive attitudes than male students and then senior student more than joiner.

Table 1. Mean, Standard deviation, and percentage of student attitudes on Relevance of Simulation subscale

\begin{tabular}{|l|l|c|c|c|c|c|}
\hline \multicolumn{1}{|c|}{ Relevance of Simulation } & N & Mean & SD & \% & Scores weight \\
\hline 1. & $\begin{array}{l}\text { "Simulation is a good environment for learning with } \\
\text { other health care professionals }\end{array}$ & 150 & 3.99 & 0.9 & 79.8 & Agree \\
\hline 2. & Simulation supports opportunities to change attitudes & 150 & 3.81 & 1.13 & 76.2 & Agree \\
\hline 3. & $\begin{array}{l}\text { Opportunities to practice teamwork can help students } \\
\text { learn about inter-professional roles }\end{array}$ & 150 & 4.01 & 1.16 & 80.2 & Agree \\
\hline 4. & $\begin{array}{l}\text { Opportunities to learn with other health care profession- } \\
\text { als has increased my understanding of their roles }\end{array}$ & 150 & 3.9 & 1.24 & 78 & Agree \\
\hline 5. $\begin{array}{l}\text { Simulation is a good tool for practicing team decision- } \\
\text { making skills }\end{array}$ & 150 & 3.8 & 1.26 & 76.6 & Agree \\
\hline 6. & $\begin{array}{l}\text { Deliberate practice can improve clinical decision-making } \\
\text { skills }\end{array}$ & 150 & 3.82 & 1.24 & 76.4 & Agree \\
\hline & $\begin{array}{l}\text { Total } \\
\text { Chi-Sq }=11.792, \text { DF }=20, \text { P-Value }=0.923\end{array}$ & 150 & 1.1 & 77.8 & Agree \\
\hline
\end{tabular}

Table 2. Mean, Standard deviation, and percentage of student attitudes on Opportunities (IPE) subscale

\begin{tabular}{|l|l|c|c|c|c|c|}
\hline \multicolumn{1}{|c|}{ Opportunities (IPE) } & N & Mean & SD & \% & Scores weight \\
\hline 1. & $\begin{array}{l}\text { Learning with other professionals is important to collabora- } \\
\text { tion }\end{array}$ & 150 & 3.66 & 1.27 & 73.2 & Agree \\
\hline 2. & $\begin{array}{l}\text { Opportunities to learn with other professionals should be a } \\
\text { priority in my education }\end{array}$ & 150 & 3.17 & 1.54 & 63.4 & Neutral \\
\hline 3. & I want more opportunities to learn with other professionals & 150 & 3.78 & 1.37 & 75.6 & Agree \\
\hline 4. & $\begin{array}{l}\text { Shared learning with other team members will improve my } \\
\text { ability to understand clinical problems }\end{array}$ & 150 & 3.56 & 1.47 & 71.2 & Agree \\
\hline 5. & $\begin{array}{l}\text { Attitudes about teamwork can change through opportuni- } \\
\text { ties to work with other professionals in simulation }\end{array}$ & 150 & 3.42 & 1.42 & 68.4 & Agree \\
\hline
\end{tabular}




\begin{tabular}{|l|l|c|c|c|c|c|}
\hline 6. & $\begin{array}{l}\text { Learning with other health care professionals before quali- } \\
\text { fication is important for the development of future inter- } \\
\text { professional relationships }\end{array}$ & 150 & 3.28 & 1.58 & 65.6 & Neutral \\
\hline 7 & $\begin{array}{l}\text { Inter professional opportunities for learning will improve } \\
\text { patients' outcomes }\end{array}$ & 150 & 3.38 & 1.45 & 67.6 & Neutral \\
\hline Total & 150 & 3.46 & 1.4 & 69.2 & Neutral \\
\hline Chi-Sq $=20.809, \mathrm{DF}=24, \mathrm{P}-$ Value $=0.650$ & &
\end{tabular}

Table 3. Mean, Standard deviation, and percentage of student attitudes on communication subscale

\begin{tabular}{|c|c|c|c|c|c|c|}
\hline No & Communication & $\mathbf{N}$ & Mean & SD & $\%$ & Scores weight \\
\hline 1 & $\begin{array}{l}\text { All students should learn how to work in the } \\
\text { context of health care teams }\end{array}$ & 150 & 3.6 & 1.23 & 72 & Agree \\
\hline 2 & $\begin{array}{l}\text { Team leaders should provide frequent patient } \\
\text { updates to other team members }\end{array}$ & 150 & 3.11 & 1.47 & 62.2 & Neutral \\
\hline 3 & $\begin{array}{l}\text { Team leaders should encourage team members to } \\
\text { ask questions }\end{array}$ & 150 & 3.62 & 1.39 & 72.4 & Agree \\
\hline 4 & $\begin{array}{l}\text { Communication within the team is as important } \\
\text { as technical skills }\end{array}$ & 150 & 3.54 & 1.46 & 70.8 & Agree \\
\hline 5 & $\begin{array}{l}\text { Team members providing immediate patient care } \\
\text { management should verbalize their activities } \\
\text { aloud }\end{array}$ & 150 & 3.37 & 1.38 & 67.4 & Neutral \\
\hline 6 & $\begin{array}{l}\text { Team members should paraphrase or repeat back } \\
\text { instructions to clarify their understanding }\end{array}$ & 150 & 3.24 & 1.56 & 65.4 & Neutral \\
\hline 7 & $\begin{array}{l}\text { Communication in teamwork is important to } \\
\text { patient safety }\end{array}$ & 150 & 3.36 & 1.43 & 67.2 & Neutral \\
\hline 8 & $\begin{array}{l}\text { The roles of non-leading members of the team are } \\
\text { just as important for good team functioning as the } \\
\text { role of the leader }\end{array}$ & 150 & 3.25 & 1.46 & 65 & Neutral \\
\hline & Total & 150 & 3.39 & 1.44 & 67.8 & Neutral \\
\hline & \multicolumn{6}{|c|}{ Chi-Sq $=22.288, \mathrm{DF}=28, \mathrm{P}-$ Value $=0.768$} \\
\hline
\end{tabular}

Table 4. Mean, Standard deviation, and percentage of student attitudes on Roles and Responsibilities subscale

\begin{tabular}{|c|l|c|c|c|c|c|}
\hline No & \multicolumn{1}{|c|}{ Roles and Responsibilities } & N & Mean & SD & \% & Scores weight \\
\hline 1 & $\begin{array}{l}\text { Teamwork practice will provide me with feedback to } \\
\text { enhance my ability to provide optimal patient care }\end{array}$ & 150 & 4.27 & 1.1 & 85.4 & Strongly agree \\
\hline 2 & $\begin{array}{l}\text { Monitoring what each team member is doing is im- } \\
\text { portant to optimize patient safety }\end{array}$ & 150 & 4.17 & 1.16 & 83.4 & Agree \\
\hline 3 & $\begin{array}{l}\text { Will enhance other team members understanding of my } \\
\text { role in patient health care }\end{array}$ & 150 & 4.15 & 1.12 & 83 & Agree \\
\hline 4 & $\begin{array}{l}\text { Teamwork practice will help me recognize how best to } \\
\text { help other team members complete their tasks }\end{array}$ & 150 & 4.34 & 1.08 & 86.8 & Strongly agree \\
\hline 5 & $\begin{array}{l}\text { It is important for team members to ask for assistance } \\
\text { if they need support in completing a task }\end{array}$ & 150 & 4.1 & 1.14 & 82 & Agree \\
\hline 6 & $\begin{array}{l}\text { Teamwork practice allows for flexibility in roles during } \\
\text { times of crisis }\end{array}$ & 150 & 4.2 & 1.1 & 84 & Strongly agree \\
\hline 7 & Total & 150 & 4.21 & 1.12 & 84.2 & Strongly agree \\
\hline & \multicolumn{2}{|l|}{ Chi-Sq = 4.563, DF =20, P-Value =1.000 } \\
\hline
\end{tabular}


Table 5. Table (5) Table (4) Mean, Standard deviation, and percentage of student attitudes on Situation Awareness subscale

\begin{tabular}{|c|c|c|c|c|c|c|}
\hline No & Situation Awareness & $\mathbf{N}$ & Mean & SD & $\%$ & Scores weight \\
\hline 1 & $\begin{array}{l}\text { I will speak up if I perceive a problem regardless of who } \\
\text { might be affected }\end{array}$ & 150 & 3.47 & 1.61 & 69.4 & Agree \\
\hline 2 & $\begin{array}{l}\text { Patient care is improved when all team members have a } \\
\text { shared understanding about the assessment and treatment }\end{array}$ & 150 & 3.37 & 1.61 & 67.4 & Neutral \\
\hline 3 & $\begin{array}{l}\text { Team leaders should provide frequent summaries of } \\
\text { patient findings to keep team members oriented to } \\
\text { patient needs" }\end{array}$ & 150 & 3.35 & 1.57 & 67 & Neutral \\
\hline & Total & 150 & 3.4 & 1.6 & 68 & Agree \\
\hline & \multicolumn{6}{|c|}{ Chi-Sq $=99.304$, DF $=8, \mathrm{P}-$ Value $=0.000$} \\
\hline
\end{tabular}

Table 6. Comparesion between student attitudes according to tier geneder

\begin{tabular}{|l|c|c|c|c|c|c|}
\hline & \multicolumn{2}{|c|}{ Male } & \multicolumn{2}{c|}{ Female } & t & P \\
\hline Subscales & Mean & SD & Mean & SD & & \\
\hline Relevance of Simulation & 25 & 1.2 & 27 & 1.4 & 2.4 & 0.5 \\
\hline Opportunities (IPE) & 31 & 0.9 & 33 & 0.3 & 3.1 & 0.5 \\
\hline Communication & 36 & 1.7 & 39 & 1.9 & 2.9 & 0.5 \\
\hline Roles and Responsibilities & 31 & 2.1 & 34 & 1.2 & 3.7 & 0.5 \\
\hline Situation Awareness & 12 & 0.4 & 14 & 0.1 & 3.8 & 0.5 \\
\hline Total & 66.3 & 6.9 & 70.4 & 4.3 & 4.2 & 0.5 \\
\hline
\end{tabular}

Table 7. One way anaylsis of variance opfr the difernces between student attitudes according to thier garde

\begin{tabular}{|c|c|c|c|c|c|c|}
\hline KidSim subscale & Source of variance & Sum of Squares & df & Mean Square & $\mathbf{F}$ & Sig. \\
\hline \multirow{3}{*}{ Relevance of Simulation } & Between Groups & 51.899 & 2 & 25.949 & 0.527 & 0.592 \\
\hline & Within Groups & 7244.394 & 147 & 49.282 & & \\
\hline & Total & 7296.293 & 149 & & & \\
\hline \multirow{3}{*}{ Opportunities (IPE) } & Between Groups & 14.075 & 2 & 7.038 & 0.455 & 0.635 \\
\hline & Within Groups & 2272.385 & 147 & 15.458 & & \\
\hline & Total & 2286.460 & 149 & & & \\
\hline \multirow{3}{*}{ Communication } & Between Groups & 21.543 & 2 & 10.772 & 0.985 & 0.376 \\
\hline & Within Groups & 1607.817 & 147 & 10.938 & & \\
\hline & Total & 1629.360 & 149 & & & \\
\hline \multirow{3}{*}{ Roles and Responsibilities } & Between Groups & 140.678 & 2 & 70.339 & 1.262 & 0.286 \\
\hline & Within Groups & 8192.822 & 147 & 55.733 & & \\
\hline & Total & 8333.500 & 149 & & & \\
\hline \multirow{3}{*}{ Situation Awareness } & Between Groups & 6.481 & 2 & 3.240 & 0.193 & 0.825 \\
\hline & Within Groups & 2465.259 & 147 & 16.770 & & \\
\hline & Total & 2471.740 & 149 & & & \\
\hline \multirow{3}{*}{ Total scores } & Between Groups & 2.030 & 2 & 1.015 & 0.623 & 0.538 \\
\hline & Within Groups & 239.543 & 147 & 1.630 & & \\
\hline & Total & 241.573 & 149 & & & \\
\hline
\end{tabular}




\section{Discussion}

In recent years, Iraqi nursing education has witnessed significant progress and development. This may be due to several factors. The most prominent of these was the adoption of Iraq a national strategy for nursing and midwifery development sponsored by the World Health Organization, which led to a comprehensive modernization of Nursing education curricula and methods of teaching. In harmony with this strategy, the educational laboratories have been developed and the simulation technology has been used in the nursing education.

This study was conducted for the purpose of measuring the attitudes of nursing students towards simulation technology in nursing education. The study offers some important insights into nursing education modes. The most interesting finding was that majority of the participating students had positive attitudes toward the simulation system in teaching nursing skills. The students believed that the simulation technology provided them with opportunities to develop their skills before applying caring the patients in real practice and they also believed that the simulation offer Opportunities to learn with other health care professionals and increased understanding of their roles.

As mentioned in the literature review, the results of this study were agreed with several other studies conducted on nursing students. Franc-Law's et al's study, [34] reveals that the overall medical students' satisfaction a with simulated based curriculum was high ( 8 of 10 on a Likert scale). Traynor et al [35] and Ennen \& Satin, [36 who reported that students gain knowledge and confidence during simulation sessions for clinical practice and improves communication and team work in emergency situations.

Another study carried out by Chakravarthy et al in 2011 [37] on the students of the medical school who were trained in the course of emergency medicine and used the simulation technology, they showed high progress in the level of knowledge and gain leadership skills and improve their level of satisfaction.

In 2006, a comparative study was conducted at the University of California, which concluded that students who received simulation training were showed better knowledge than practice-based learning [18].

Furthermore, a study revealed high student agreement scores for material taught with simulation compared with more traditional modalities such as Power Point lecture, self-study session, and group discussion [38-40]. These studies concluded that the use of simulation in the training of nursing students was positively reflected in the promotion of students' practices and their ability to acquire new skills and develop their ability to brainstorming, reasoning and critical thinking in solving problems. In addition, some studies confirmed that students who were trained by simulation showed less clinical errors in the clinical setting and were abler to make clinical decisions [41-42].

Indeed, many studies shows that that good preparation, pragmatism, and interrogation sessions are vital to successful clinical simulations that endorse practical and nonpractical skill attainment, enhanced levels of self-reliance, teamwork, and patient safety [43-44]. 
Generally, the students' positive attitudes toward simulation technology were found more among female students than male students, and this may be due to the fact that females have a higher level of anxiety than males during training in nursing skills, especially on patients directly Simulations also enhance self-confidence.

These results were consistent with those of some previous studies. It was observed that the favorable perception toward SBL was significantly higher $(p=0.04)$ among female Indian students as reported by Joseph et al. [45].

In particular, has focused on the in another study conducted to evaluate medical students' satisfaction with Simulation based learning (SBL) strategy at the College of Medicine, King Saud bin Abdul-Aziz University for Health Sciences, Riyadh, Saudi Arabia, it was noticed that the female third year medical students were significantly ( $\mathrm{p}$ $=0.03$ ) more satisfied with the SDL compared with the males (54 \pm 7 vs. $50 \pm 9$ ).[46] Nursing education is based on three important pillars: knowledge, practice, and attitudes. Nursing students receive extensive theoretical information in the classroom and are trained to practice care in educational laboratories. [46]

The emotional aspect of caring for patients and moral and legal issues cannot be overlooked because man is the highest value in society [47-49]. Similarly, Baxter et al [50] Kiat et al [51] determined in their study that when theoretical education is combined with practice, simulation technology becomes a fun way to teach, and the skills of students become more efficient and unusual, and the they become aware of what he is doing differently. In the same way a study conducted by Wotton et al [30] on the third-grade students used advanced manikin showed that most students had positive attitudes about the use of high -fidelity simulation manikin.

The nursing students revealed a high positive attitude toward the simulation experience in all grades. Unlike results were shown in Mould et. al. [52] and Baillie \& Curzio, [53] where the students knowledgeable an improvement in nursing competence, confidence and increased skill post the simulation experience. In Sullivan Mann et. al., [54], the results revealed that the trial contributors showed improved score level in critical thinking. Likewise, another study conducted by Kiat et al [51], on the second-graders nursing students showed that they learned from their mistakes and their self-esteem increased. Correspondingly a previous study showed that simulation technology is useful and valuable in training students and providing minimum technical skills [55-67].

\section{Conclusion}

The ability to simulate patients has become more sophisticated with great technological advances and virtual reality has become fairly real in terms of education and training. Nursing education and training is progressing remarkably and requires a high level of attention in assessment methods, such as problem solving and critical thinking. The simulation offers opportunities for education and training in a safe and secure environment. Current research is not enough to support the idea that simulation replaces clinical education, but simulation remains an excellent bridge between theoret- 
ical framework and application. This study has found that generally, Mosul Nursing students has positive attitudes towards using simulation in their teaching and training.

\section{$8 \quad$ Recommendation}

Nursing educators should be familiar with the ways in which simulation technology can be used as an important learning tool, being aware of its benefits and how to motivate students to master it. The use of appropriate scenarios may be of great benefit to the understanding and considerate of the skills of students in solving problems. Therefore, the nursing teachers should be very careful in the adoption of the means of student's assessment needs and implement course plan and evaluation the outcome

\section{Conflict of Interest}

I declare that I DO NOT have any conflicts of interest.

\section{References}

[1] Sugandi L, Kurniawan Y. (2018). (The Influence of Information Technology on the Information and Service Quality for the Teaching and Learning, International Journal of Emerging Technologies in Learning (IJET) - 13, (12), 230-237.https://doi.org/10. 3991/ijet.v13i12.8665

[2] Al-Alwani. (2014). An Information Technology Integration in Higher Education a Novel Approach for Impact Assessment, International Journal of Emerging Technologies in Learning (IJET) - 9, (6), 32-36. https://doi.org/10.3991/ijet.v9i6.4036

[3] Kalogiannakis, M., \& Papadakis, St. (2007). The dual form of further education of educators in ICT: technological and pedagogical training. In C. Constantinou, Z. Zacharias \& M. Papaevripidou (Eds.) Proceedings of the 8th International Conference on Computer Based Learning in Science, Heraklion, 30 June - 6 July 2007, 265-276.

[4] Kikilias, P., Papachristos, D., Alafodimos, N., Kalogiannakis, M. \& Papadakis, St. (2009). An Educational Model for Asynchronous E-Learning. A case study in a Higher Technology Education, In D. Guralnick (ed.) Proceedings of the International Conference on E-Learning in the Workplace (ICELW-09), 10-12 June 2009, New York: Kaleidoscope Learning (CDRom).

[5] Kalogiannakis, M., Vassilakis, K., Alafodimos, C., Papadakis, St., Papachristos, D., \& Zafeiri, E. (2009). Adult Education and Lifelong Learning: A Greek Case Study. International Journal of Advanced Corporate Learning, 2(4), 15-20. https://doi.org/10. 3991/ijac.v2i4.981

[6] Garba, S., Yusuf, B., \& Busthami, A. (2015). Toward the Use of Technology and 21st Century Teaching-learning Approaches: The Trend of Development in Malaysian Schools within the Context of Asia Pacific. International Journal of Emerging Technologies in Learning (IJET), 10(4), pp. 72-79. https://doi.org/10.3991/ijet.v10i4.4717

[7] Papastavrou E, Lambrinou E, Tsangari H, Saarikoski M, Leino-Kilpi H. (2010). Student nurses experience of learning in the clinical environment. Nurse Education Practice. 10:17682. https://doi.org/10.1016/j.nepr.2009.07.003 
[8] Muniasamy V, Eljailani I, Anandhavall, M. (2019). Student's Performance Assessment and Learning Skill towards Wireless Network Simulation Tool - Cisco Packet Tracer. International Journal of Emerging Technologies in Learning (IJET) - 14(7), 196-208. https://doi.org/10.3991/ijet.v14i07.10351

[9] Application of Visual Simulation Technology in College English Teaching, Bing-jun Ma Fuyang Normal College, Fuyang, China.

Online: https://online-journals.org/index.php/ijet/article/view/6243/4195.

[10] Chen J, PE. (2018). Teaching Activities in Colleges and Universities Based on Decision Tree. iJET - 13 (8) ,38-50. https://doi.org/10.3991/ijet.v13i08.8693

[11] Eligible A, Yildirim Sari H. (2007). Determining problems experienced by student nurses in their work with clinical educators in Turkey. Nurse Education Today; 27:491-8. https://doi.org/10.1016/j.nedt.2006.08.011

[12] Bartz C, Dean-Baar S. (2003). Reshaping clinical nursing education: An academic-service partnership. J Prof Nurs.19:216-22. https://doi.org/10.1016/S8755-7223(03)00090-5

[13] Orton VM. (2007). Nurses as Clinical Teachers: Variables Affecting Teaching Comfort and Self-Efficacy. University of Southern California.

[14] Akhu-Zaheya, L., Gharaibeh, M., \& Alostaz, Z. (2012). Effectiveness of simulation on knowledge acquisition, knowledge retention, and self-efficacy of nursing students in Jordan. Clinical Simulation in Nursing. 9: 335-342. https://doi.org/10.1016/j.ecns.2012.05.001

[15] World Health Organization. (2011). Patient safety curriculum guide: Multi-professional edition.

[16] Arthur, C., Levett-Jones, T., Kable, A. (2013). Quality indicators for design and implementation of simulation experiences: A Delphi study. Nurse Education Today. 33 (11): 13571361. https://doi.org/10.1016/i.nedt.2012.07.012

[17] Blum, C. A., \& Parcells, D. A. (2012). Relationship between high-fidelity simulation and patient safety in pre licensure nursing education: A comprehensive review. Journal of Nursing Education. 51:429-435. https://doi.org/10.3928/01484834-20120523-01

[18] California Board of Registered Nursing, Title 16, California code of regulations. Article 3. Pre licensure nursing programs. 2015 Retrieved from http://www.rn.ca.gov/ regulations/title16.shtml\#1426

[19] Schiavenato, M. (2009). Reevaluating simulation in nursing education: Beyond the human patient simulator. Journal of Nursing Education. 48: 388-394.https://doi.org/10. $\underline{3928 / 01484834-20090615-06}$

[20] Colorado Department of Regulatory Agencies Board of Nursing. Department of regulatory agencies: division of professions and occupations. Chapter 2 - rules and regulations for approval of nursing education programs. 2015 Retrieved from http://cdn. colorado.gov/cs/Satellite/DORA-Reg/CBON/DORA/1251631690394.

[21] Crytzer, M.L. (2011). The effect of high-fidelity home health simulations on nursing students' clinical performance (doctoral dissertation). Available from ProQuest Dissertations and Theses Global (UMI No. 3486967).

[22] Darcy Mahoney, A.E., Hancock, L.E., Iorianni-Cimbak, A., Curley, M.A.Q. (2013). Using high-fidelity simulation to bridge clinical and classroom learning in undergraduate pediatric nursing. Nurse Education Today; 33 (6): 648-654. $\underline{\text { https://doi.org/10. }}$ 1016/j.nedt.2012.01.005

[23] DE Carlo, D., Colling ridge, D. S., Grant, C., \& Ventre, K. M. (2008). Factors influencing nurses' attitudes toward simulation-based education. Simulation in Healthcare. 3: 90-96. https://doi.org/10.1097/SIH.0b013e318165819e 
[24] Fabro, K., Schaffer, M., Scharton, J. (2014). The development, implementation, and evaluation of an end-of-life simulation experience for baccalaureate nursing students. Nurs. Educ. Perspect. 35 (1): 19-25. https://doi.org/10.5480/11-593.1

[25] Gates, M.G., Parr, M.B., Hughen, J.E. (2012). Enhancing nursing knowledge using highfidelity simulation. J. Nursing. Education. 51 (1): 9-15. https://doi.org/10.3928/0148483420111116-01

[26] Martins J. (2017). Aprendizagem e desenvolvimento em contexto de prática simulada. Revista de Enfermagem Referência IV (12):155-62. https://doi.org/10.12707/RIV16074

[27] Park K, Ahn Y, Kang N, Sohn M. (2016). Development of a simulation-based assessment to evaluate the clinical competencies of Korean nursing students. Nurse Education Today. 36:337-41. https://doi.org/10.1016/j.nedt.2015.08.020

[28] Prince L., Winmill D., Wing D., Kahoush A. Nursing Students' Perceptions of a MultiplePatient Simulation Experience. Nursing Education Perspectives 37 (6), 331-332. https://doi.org/10.1097/01.NEP.0000000000000046

[29] Leonard, B., Shuhaibar, E. L., \& Chen, R. (2010). Nursing student perceptions of intraprofessional team education using high-fidelity simulation. Journal of Nursing Education. 49: 628-631. https://doi.org/10.3928/01484834-20100730-06

[30] Wotton, K., Davis, J., Button, D., \& Kelton, M. (2010). Third year undergraduate nursing students' perceptions of high-fidelity simulation. Journal of Nursing Education. 49: 632-639. https://doi.org/10.3928/01484834-20100831-01

[31] Tosterud, R., Hedelin, B., \& Hall-Lord, M. L. (2013). Nursing students' perceptions of high- and low-fidelity simulation used as learning methods. Nurse Education in Practice, 13,262-270. https://doi.org/10.1016/j.nepr.2013.02.002

[32] Gharaibeh B, Hweidi I, and Al-Smadi A. (2017). Attitudes and perception of baccalaureate nursing students toward educational simulation. Cogent Education, 4: 1360063. https://doi.org/10.1080/2331186X.2017.1360063

[33] Sigalet, E., Donnon, T., \& Grant, V. (2012). Undergraduate students' perceptions of and attitudes toward a simulation-based interprofessional curriculum: The KidSIM ATTITUDES questionnaire. Simulation in Healthcare. 7: 353-358. https://doi.org/10.

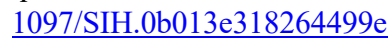

[34] Franc-Law J, Ingrassia P, Ragazzoni L, Corte F. (2010). The effectiveness of training with an emergency department simulator on medical student performance in a simulated disaster. Canadian J Emerge Med 12: 27-32.

[35] Traynor M, Gallagher A, Martin L, Smyth S. (2010). From novice to expert: Using simulators https://doi.org/10.12968/bjon.2010.19.22.1422

[36] Ennen CS, Satin AJ. (2010). Training and assessment in obstetrics: The role of simulation. Best Pact Res Clan Oster Gynaecol 24: 747-758. https://doi.org/10. 1016/j.bpobgyn.2010.03.003

[37] Chakravarthy B, Ter Haar E, Bhat SS, McCoy CE, Denmark TK, Lotfipour S. (2011). Simulation in medical school education: review for emergency medicine. West $J$ Emerg Med 12:461-466. https://doi.org/10.5811/westjem.2010.10.1909

[38] Nguyen HB, Daniel-Underwood L, Van Ginkel C, Wong M, Lee D, Lucas AS, et al. (2009). An educational course including medical simulation for early goal-directed therapy and the severe sepsis resuscitation bundle: an evaluation for medical student training. Resuscitation 80: 674-679. https://doi.org/10.1016/j.resuscitation.2009.02.021

[39] Steadman RH, Coates WC, Huang YM, Matevosian R, Larmon BR, McCullough L, et al. (2006). Simulation-based training is superior to problem-based learning for the acquisition of critical assessment and management skills. Crit Care Med 34:151-157. https://doi.org/10. $\underline{1097 / 01 . C C M .0000190619 .42013 .94 ~}$ 
[40] Norman, J. (2012). Systematic review of the literature on simulation in nursing education. Journal of the Association of Black Nursing Faculty. 23: 24-28.

[41] Ogilvie, S., Cragg, B., \& Foulds, B. (2011). Perceptions of nursing students on the process and outcomes of a simulation experience. Nurse Education. 36: 56-58. https://doi.org/10. 1097/NNE.0b013e31820b4fd5

[42] Peisachovich, E., Gal, R., \& Johnson, S. (2016). Experiences of undergraduate nursing students of standardized patient methodology in their transition to nursing practice in Ontario Canada. Journal of Nursing Education and Practice. 7(3): 1-9. doi:10.5430/jnep. v7n3p1 https://doi.org/10.5430/jnep.v7n3p1

[43] Pickens, J. (2005). Attitudes and perceptions. In N. Borkowski, Organizational behavior in health care. 2nd ed. pp. 43-69.

[44] Cant, R. P., \& Cooper, S. J. (2010). Simulation-based learning in nurse education: Systematic review. Journal of Advanced Nursing. 66: 3-15.https://doi.org/10.1111/j.13652648.2009.05240.x

[45] Joseph N, Nelliyanil M, Jindal S, Utkarsha, Abraham AE, Alok Y, et al. (2015). Perception of simulation-based learning among medical students in South India. Ann Med Health Sci Res 5(4):247-52. https://doi.org/10.4103/2141-9248.160186

[46] Goris, S., Bilgi, N., Korkut Bayındır, S. (2014). The use of simulators in nursing education. Düzce University Health Sciences Institute Journal. 4(2): 25-29.

[47] Wilford, A., \& Doyle, J. T. (2006). Integrating simulation training into the nursing curriculum. British Journal of Nursing. 15: 926-930.https://doi.org/10. 12968/bjon.2006.15.17.21907

[48] Agha, Sajida \& Y Alhamrani, Asma \& Khan, Anwar. (2015). Satisfaction of medical students with simulation-based learning. Saudi Medical Journal. 36: 731-6. https://doi.org/10.15537/smj.2015.6.11501

[49] Yeun, E. J., Bang, H. Y., Ryoo, E. N., \& Ha, E. H. (2014). Attitudes toward simulation=based learning in nursing students: An application of Q methodology. Nurse Education. Today, 34: 1062-1068.

[50] Baxter, P., Akhtar-Danesh, N., Valaitis, R., Stanyon, W., \& Sproul, S. (2009). Simulated experiences: Nursing students share their perspectives. Nurse Education. Today, 29: 859-866.: https://doi.org/10.1016/j.nedt.2009.05.003

[51] Kiat, T.K. \& Mei, T.T.Y. \& Nagammal, S \& Jonnie, A.D.A.J. (2007). A review of learners' experience with simulation-based training in nursing. Singapore Nursing Journal. 34: 37-43.

[52] Mould, J., White, H. \& Gallagher, R. 2011. Evaluation of a critical care simulation series for undergraduate nursing students. Contemporary Nurse 38 (1-2), 180 -190https://doi.org/10. 5172/conu.2011.38.1-2.180

[53] Baillie, L. \&Curzio, J. 2008. Students' and facilitators' perceptions of simulation in practice learning. Nurse Education in Practices 9(5), 279 -306. https://doi.org/10. 1016/j.nepr.2008.08.007

[54] Sullivan-Mann, J., Perron, C. \&Fellner, A. 2009. The effects of simulation on nursing students' critical thinking scores: A quantitative study. Newborn and Infant Nursing Reviews 9(2), 111-116. https://doi.org/10.1053/j.nainr.2009.03.006

[55] Alinier, G. (2006). Effectiveness of intermediate fidelity simulation training technology in undergraduate nursing education, Journal of Nursing. 54(3): 359-369 https://doi.org/10.1111/j.1365-2648.2006.03810.x

[56] Meyer, M., Connors, H., Hou, Q., \& Gajewski, B. (2011). The effect of simulation on clinical performance: A junior nursing student clinical comparison study. Simulation in Healthcare. 6: 269-277. https://doi.org/10.1097/SIH.0b013e318223a048 
[57] Roh, Y.S., Kim, S.S., Kim, S.H. (2014). Effects of an integrated problem-based learning and simulation course for nursing students. Nursing and Health Sciences. 16: 91-96. https://doi.org/10.1111/nhs.12069

[58] Wang, A.L., Fitzpatrick, J.J., Petrini, M.A. (2014). Use of simulation among Chinese nursing students. Clinical Simulation in Nursing. 9 (8): 311-317. https://doi.org/10. 1016/j.ecns.2012.03.004

[59] Aqel, A.A. \& Ahmad, M.A. (2014). High-fidelity simulation effects on CPR knowledge, skills, acquisition, and retention in nursing students, Worldviews on Evidence-Based Nursing. 11(6):394-400. https://doi.org/10.1111/wvn.12063

[60] Jeffries, P. R. (2005). A framework for designing, implementing, and evaluating simulations used as teaching strategies in nursing. Nursing Education Perspectives. 26: 96-103.

[61] Kaakinen, J., \& Arwood, E. (2009). Systematic review of nursing simulation literature for use of learning theory. International Journal of Nursing Education Scholarship. 6(1). https://doi.org/10.2202/1548-923X.1688

[62] Kiang Wu Nursing College of Macau. (2015). The Curriculum of Baccalaureate Nursing (BSN) Program. Kiang Wu Nursing College of Macau, Macau.

[63] Levett-Jones, T., Lapkin, S., Hoffman, K., Arthur, C., Roche, J., 2011. Examining the impact of high and medium fidelity simulation experiences on nursing students' knowledge acquisition. Nurse Educ. Pract. 11 (6): 380-383. https://doi.org/10.1016/j.nepr.2011.03.014

[64] Kim, H., Schwartz-Barcott, D., Holter, I., \& Lorensen, M. (1995). Developing a translation of the McGill pain questionnaire for cross-cultural comparison: An example from Norway. Journal of Advanced Nursing. 21: 421-426. https://doi.org/10.1111/j.13652648.1995.tb02722.x

[65] Kutner, M., Nachtsheim, C., \& Neter, J. (2004). Applied linear regression models (4th ed.). Boston, MA: McGraw-Hill. Lateef, F. (2010). Simulation-based learning: Just like the real thing. Journal of Emergencies, Trauma and Shock. 3: 348- 352.https://doi.org/10. $\underline{\text { 4103/0974-2700.70743 }}$

[66] Leigh, G. T. (2008). High-fidelity patient simulation and nursing students' self-efficacy: A review of the literature. International Journal of Nursing Education Scholarship. 5(1): 1-17. https://doi.org/10.2202/1548-923X.1613

[67] Gordon, C. J., \& Buckley, T. (2009). The effect of high-fidelity simulation training on medical-surgical graduate nurses' perceived ability to respond to patient clinical emergencies. The Journal of Continuing Education in Nursing. 40: 491- 498.https://doi.org/10. 3928/00220124-20091023-06

\section{Acknowledgement}

I would like to express my special thanks of gratitude to deanship of Nursing College at University of Mosul as well as Nursing Students who agreed and gave me the golden opportunity to do this wonderful work.

\section{Authors}

Mohammad Salih Awad is an Assistant Lecturer at Clinical Nursing Sciences, College of Nursing, University of Mosul, Iraq (mohammed.salih@uomosul.edu.iq). 
Mr. Mohanned Khalil Abdullah has done M.Sc. Nursing. He is an Assistant Lecturer, Clinical Nursing Sciences department at College of Nursing, University of Mosul, Mosul City, Iraq.

Dr. Radhwan Hussein Ibrahim is a Professor of Community Health Nursing, Dean, College of Nursing, University of Mosul, Mosul City, Iraq (mail.prof.dr.radhwan@uomosul.edu.iq).

Mr. Rezgar Khalil Abdullah has done M.Sc. in Fundamentals of Nursing, OH, Mosul City, Iraq. He is with the Ministry of Health, Nineveh Directorate, Mosul, Iraq.

Article submitted 2019-03-30. Resubmitted 2019-05-05. Final acceptance 2019-05-06. Final version published as submitted by the authors. 